\title{
Remarkable discovery of the Atlanto-Mediterranean moth Scythris ventosella Chrétien, 1907 at high altitude in the Alps of Valais, Switzerland - a possible relict of the late-glacial steppe-belt fauna? (Lepidoptera, Scythrididae)
}

\author{
Jürg Schmid ${ }^{1}$ \\ 1 Poststrasse 3, CH-7130 Ilanz \\ http://zoobank.org/C9634F44-8B2E-4CD5-BF46-9429C7B23D10 \\ Corresponding author: Jürg Schmid (juerg_schmid@bluewin.ch)
}

\begin{abstract}
Received 10 January 2018

Accepted 16 April 2018

Published 8 May 2018

Academic editor:

Yannick Chittaro

\section{Key Words}

glacial relict

steppe

micromoth

high-alpine zone

The unexpected discovery of Scythris ventosella Chrétien, 1907 in the Alps of Valais, Switzerland is reported. Early stages, life cycle and habitat characteristics are described. The unusual present-day distribution of this species is discussed and it is suggested that the population in the Valais Alps may represent a relict from the late-glacial steppe-belt fauna.

\section{Zusammenfassung}

Die bemerkenswerte Entdeckung der atlanto-mediterranen Kleinschmetterlingsart Scythris ventosella Chrétien, 1907 in den Walliser Hochalpen wird mitgeteilt. Angaben zur Biologie und zum Biotop werden aufgeführt. Mögliche Erklärungen zum ungewöhnlichen Verbreitungsmuster werden diskutiert, wobei das Vorkommen als spätglaziales Steppenrelikt gedeutet werden könnte.
\end{abstract}

Swiss Alps

faunistics

\section{Introduction}

The Scythrididae are a family of small to medium-sized moths, distributed worldwide and occurring in a variety of different habitats from lowlands to high-mountain sites.

The most recent comprehensive treatment of the European and North African representatives of this family dates from 1997 and lists 237 species (Bengtsson 1997).

While some species occurring in the lowlands may be widely distributed, other taxa seem to be restricted to very small areas, especially in mountain regions thus representing local endemism (Huemer 2000). For Switzerland, 34 scythridid species are listed (SwissLepTeam 2010), eight of which however are considered doubtful records.

Alpine scythridids are usually brown, dark fuscous or greenish bronze, sometimes with some whitish marks on their forewings. They are notoriously difficult to identify based on their wing-pattern alone. Fortunately however, their male genitalia are not only rather elaborate but also very distinctive and differ considerably from species to species.

\section{Material and methods}

In July 2015, a single, unidentifiable small scythridid moth had been observed in the Zermatt mountains, Canton of Valais, Switzerland, at an altitude of $3000 \mathrm{~m}$ feeding on a flowering cushion of Silene acaulis. Unfortunately, the site was inaccessible, bordering on an abyss.

In the following year, in the same biotope at $3040 \mathrm{~m}$, a male specimen of the same species could be caught. Routine genital dissection was performed. 


\section{Results}

The male genitals surprisingly revealed characters assigning this specimen unambiguously to Scythris ventosella Chrétien, 1907 (Fig. 1).

The biotope in which $S$. ventosella was found is located at a sunny and dry south/southwest facing rocky mountain slope on calcarious ground. The sparse vegetation is characterized as association Herniarietum alpinae Zollitsch, 1968 (Steiner 2002) (Fig. 2). As mentioned above, one specimen of $S$. ventosella had been observed feeding on a cushion of Silene acaulis.

In the following year, four males and three females were sampled at the site on July 14.-15., the species was then reared from egg and the biology could be identified:

Larval foodplant is Herniaria alpina (Caryophyllaceae) (Fig. 3). The egg is white, oval with a sculptured

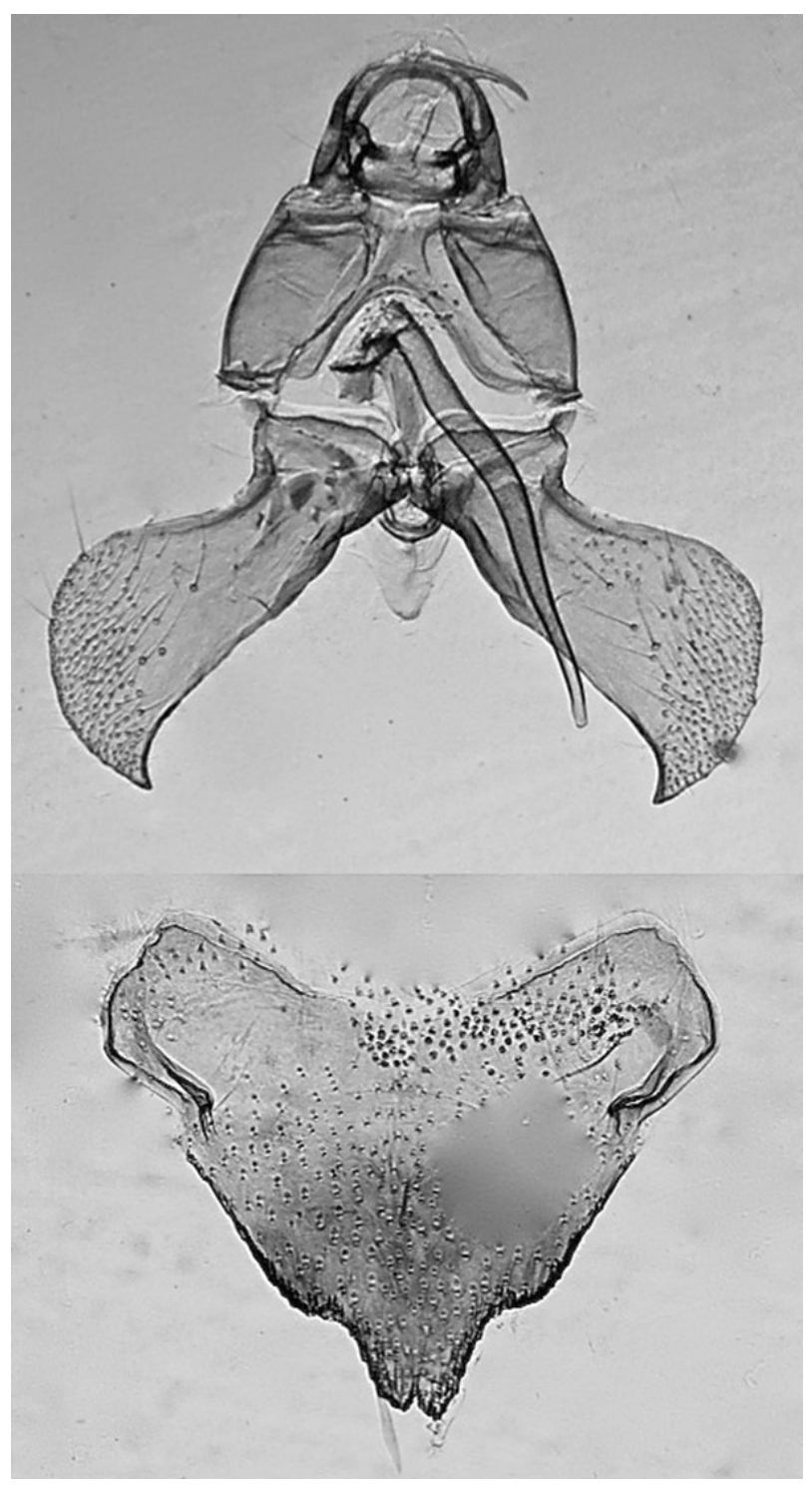

Figure 1. Male genitals (above) and sternum 8 (below) of $S$. ventosella. Site: Switzerland, Canton of Valais, Zermatt, Unterrothorn 3040 m, 6. VIII. 2016, leg., gen. prep. and coll. Jürg Schmid. surface. The young caterpillar lives in a silken tube in the plant cushion. It is of light yellowish-brown colour with irregular darker lines and marks, the pattern of which corresponds well with the caterpillars of other Scythridid species. Head and thoracic shield are dark brown. The latter is divided by a central yellowish streak that continues dorsally on the adjacent two body segments; anal shield brown (Fig.4). In autumn, the caterpillar produces a dense cocoon in which it hibernates. Most likely, the life cycle from egg to moth takes usually two years at this altitude, which means that the caterpillar will overwinter twice. Pupation takes place in a rather dense, spindle-shaped silken cocoon in the plant cushion or underneath a stone in early summer. The adult moth has a wingspan of 8-10 $\mathrm{mm}$. Freshly emerged specimens are more or less densely covered with white scales, most of which apparently are lost in the course of lifetime (Figs 5 to 7). The moth does not fly extensively but rather jumps and crawls nervously among the vegetation; it is active during the day.

\section{Mitochondrial barcode}

Legs of a male specimen were used to obtain DNA barcode sequences from the mitochondrial cytochrome oxidase-1 gene The laboratory work was executed at the Canadian Centre for DNA barcoding (CCDB Biodiversity Institute of Ontario, University of Guelph, Canada, Process-ID:LEASS470-17), using the protocol described in De Waard et al. 2008. The results were compared to the data in the Barcode of Life Data System (BOLD) (Ratnasingham and Hebert 2007). The results yielded a $100 \%$ match with the barcode of a specimen originating from the French Central Pyrenees (Gavarnie, $1450 \mathrm{~m}$ ) (Process-ID:PHLAD268-11).

\section{Discussion}

S. ventosella was described in 1907 by Chrétien from material he collected in the south of France, locus typicus being Canet (Languedoc). Only a year later, De Joannis found what he considered a new Scythridid at Plouharnel in southern Bretagne, which he named Scythris herniariae. In 1936, Zerny found a Scythridid moth in Morocco, high Atlas mountains, which he described as Scythris jugicolella.

In his revision of the Scythrididae family, Passerin d'Entrèves (1976) examined original museum material of the above mentioned taxa and came to the conclusion, that $S$. herniariae and $S$. jugicolella both were synonyms of $S$. ventosella. Finally, Vives Moreno (1984), synonymized Scythris canetella Caradja from Portugal and Spain with S. ventosella.

Thus, the currently known distribution of $S$. ventosella would place this species into the group of Atlanto-Mediterranean organisms sensu De Lattin (1967), inhabiting a geographical area in the western Mediterraneum, from southern France, French Pyrenees, Spain, Portugal to Morocco with a northern outpost in southern Bretagne (Fig. 8). 

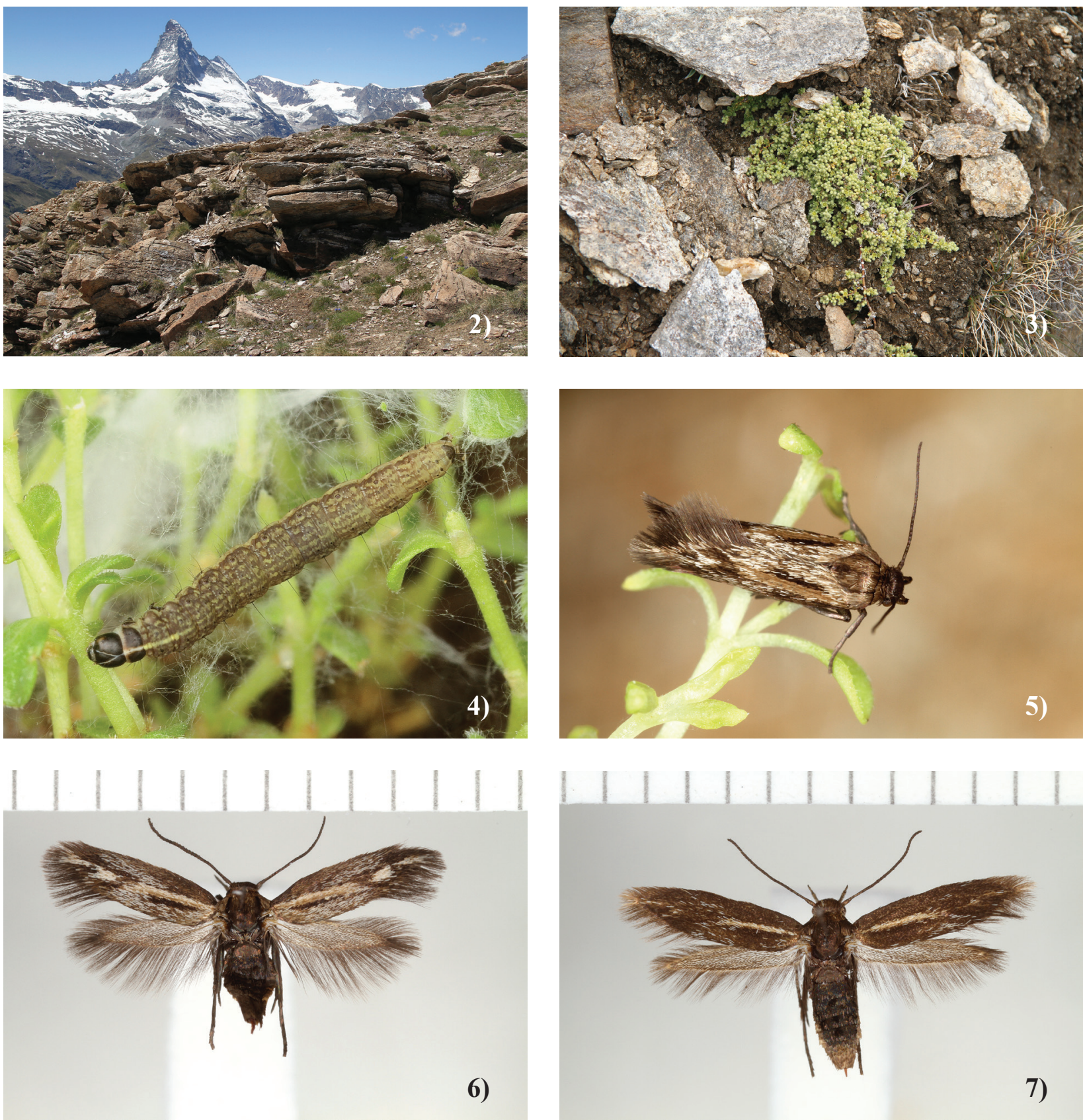

Figure 2-7. 2) Biotope, 3040m a.s.1.; 3) Herniaria alpina; 4) Adult caterpillar; 5) Freshly emerged moth; 6) Reared moth. Scale bar unit: mm; 7) Wild moth. Scale bar unit: $\mathrm{mm}$.

\section{The published data are:}

Spain: Granada Pampaneira, 1140 m (Bengtsson 1997) Portugal: Serra de Estréla, Torre, 1600-1950 m (Bengtsson 1997)

France: Canet, Languedoc (Chrétien 1907)

France: S. herniariae: Plouharnel, Bretagne; sand dunes, hostplant: Herniaria glabra (De Joannis, 1908)

France: Midi-Pyrenées, Gavarnie, 1450 m; 1.VIII.2002, leg. J. Nel (www.boldsystems.org)

Morocco: S. jugicolella Zerny 1936: Marokko, Grosser Atlas

Unfortunately, in the above-mentioned publications, very little information is given as to the climatic or botanical circumstances of the respective sites. The paucity of known sites may indicate, however, that $S$. ventosella is restricted to biotopes with narrowly defined climatic and/or botanical parameters. Bengtsson (1997) mentions Paronychia argentea as hostplant, a herb on very dry, calcareous soil (Aeschimann et al. 2004). De Joannis (1908) gives a detailed description of the caterpillar and identifies its hostplant as Herniaria glabra. This plant species prefers sandy or gravel soil in open, sunny and rather dry biotopes in low to subalpine altitudes. Its distribution in Switzerland is rather patchy but it is more common in the Valais main valley.

In contrast, Herniaria alpina grows in the subalpine and alpine zone predominantly in the western Alps. Its distribution in Switzerland is very limited; it has been found in the 


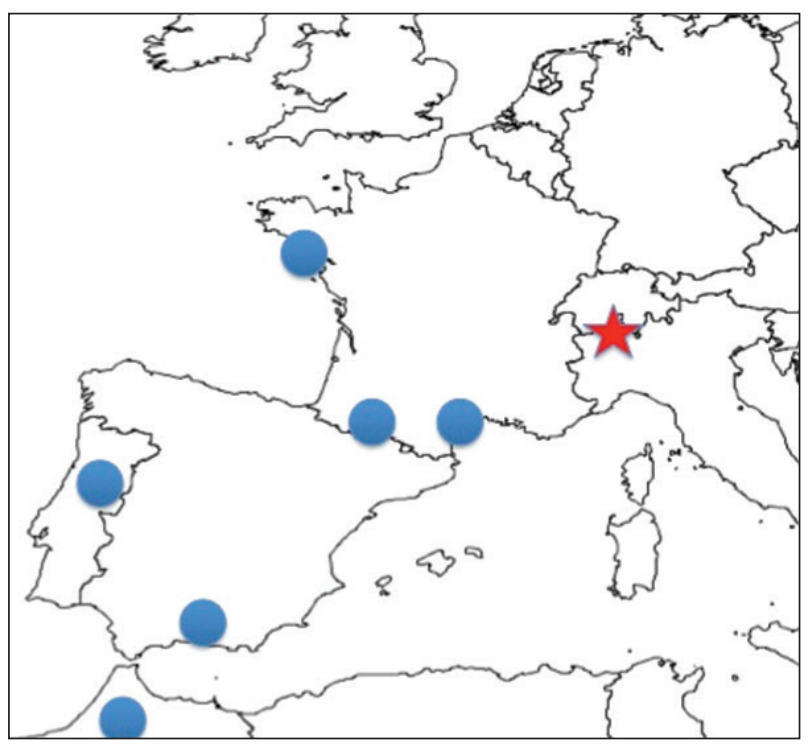

Figure 8. Currently known distribution of S. ventosella in the Alps (red asterisk) and in the Western Mediterraneum (blue dots).

southern chain of the Valais Alps, in northern Ticino and some old records exist from a few spots in central Grisons (Lauber and Wagner 1996, www.infoflora.ch).

The Zermatt region is famous for both its remarkable botanical and lepidopterological diversity, which again is derived from peculiar historical, climatic and geological conditions. A surrounding mountain chain with peaks beyond $4000 \mathrm{~m}$ shields the valley from precipitations. Genetic data have demonstrated (Bettin et al. 2007) that at least some slopes must have remained ice free during the last glaciation (nunataks) where typical steppe plants such as Astragalus exscapus, Silene vallesia, Stipa joannis, Alyssum alpestre survived to the present day (Delarze 1987, Steiner 2002). The specific biotope of $S$. ventosella is botanically characterized as Herniarietum alpinae, which includes Draba aizoides, Oxytropis helvetica and Artemisia glacialis, all plant species characteristic for very dry, soft limestone bedrock.

The exceptional altitude and the south/southwest facing exposition result in local climatic extremes: High noon ground temperatures, enhanced ultraviolet radiation, pronounced nocturnal and seasonal temperature drop in combination with very dry soil and unusual low precipitations form a microclimate somewhat comparable to a desert situation. Thus, similarities with steppes or desert-like localities in the western Mediterraneum, where $S$. ventosella locally occurs, appear not unlikely.

Organisms having survived at isolated refugia within the alpine mountain system during the entire Quaternary glaciation period, however, are expected to display considerable genetic differences when compared to their siblings having survived in peripheral refugia (Schönswetter et al. 2005). The fact that the mitochondrial barcode regions of $S$. ventosella from Zermatt and from the French Pyrenees are identical can be taken as indication that the geographic separation of these populations is recent, i.e. postglacial.
During the last glaciation, the region between the Pyrenees and the Alps was covered by tundra and cold steppe where cold-adapted organisms were able to survive. Some of these species are now restricted to high mountain areas (Habel et al. 2010). For the butterfly Erebia epiphron, a common genetic lineage between the populations of the Northern Pyrenees and the Western Alps has been documented (Schmitt 2010) thus demonstrating a once continuous area of occurrence where today only strictly separated populations thrive.

Likewise, it may be hypothesized that $S$. ventosella at a high alpine location in the Swiss Alps could be a surviving relict of the late-glacial steppe-belt which expanded from the Iberian Peninsula to the base of the ice-covered south-western Alps but must also have been in communication with selected ice-free nunataks within the alpine range. Later, in consequence of a progressively warmer and more humid postglacial climate, $S$. ventosella would have been forced to retreat to few favourable sites with dry, sunny cold microclimate such as mountain areas (Sierras) or coastal dunes, where it is found in isolated colonies to the present day. This scenario would also explain why this moth species does not accompany Herniaria glabra, the hostplant in coastal Bretagne, in the Valais main valley, where the mean annual temperatures for this insect may be much too high today.

\section{Acknowledgements}

The author would like to thank Peter Huemer, (A-Innsbruck) for his most valuable mediation to the Canadian Centre for DNA barcoding (CCDB Guelph, Ontario, Canada). To its head, Paul Hebert and his team, the author is indebted for performing DNA sequencing of a sample of $S$. ventosella from Zermatt. Conradin Burga's support in pointing to botanical literature is very much appreciated. Also, the critical comments of two reviewers, Jessica Litman and Andy Kopp and of the subject editor Yannick Chittaro have considerably improved the manuscript and are much valued. Finally, the author is indebted to Lorraine Gage Caduff (Ilanz) for checking the English language of the manuscript.

\section{References}

Aeschimann D, Lauber K, Moser DM, Theurillat J-P (2004) Flora alpina. Band 1: Lycopodiaceae-Apiaceae. Haupt, Bern-Stuttgart-Wien, $1159 \mathrm{pp}$.

Bengtsson BÅ (1997) Scythrididae. In: Huemer P, Karsholt O, Lyneborg L (Eds) Microlepidoptera of Europe 2. Apollo Books, Stenstrup, 38-39.

Bettin O, Cornejo P, Edwards J, Holderegger R (2007) Phylogeography of the high alpine plant Senecio halleri (Asteraceae) in the European Alps: in situ glacial survival with postglacial stepwise dispersal into peripheral areas. Molecular Ecology 16(12): 2517-2524. https://doi. org/10.1111/j.1365-294X.2007.03273.x 
Chrétien P (1907) Lépidoptères du Languedoc (2). Le Naturaliste, revue illustrée des sciences naturelles, 179.

Delarze R (1987) L'origine des pelouses steppiques valaisannes à la lumière de leurs liens de parenté avec les régions limitrophes. Bulletin de La Murithienne, Société valaisanne des sciences naturelles 105: 41-70.

De Joannis J (1908) Une nouvelle espèce de Scythris (Microlép.) des environs de Vannes. Bulletin de la Societé entomologique de France 1908: 248-250

De Lattin G (1967) Grundriss der Zoogeographie. Gustav Fischer, Jena, 602 pp.

De Waard JR, Ivanova NV, Hajibabaei M, Hebert PDN (2008)Assembling DNA Barcodes: Analytical Protocols. In: Cristofre M (Ed) Methods in Molecular Biology: Environmental Genetics. Humana Press Inc., Totowa, USA, 275-293. https://doi.org/10.1007/978-1-59745-548$0 \_15$

Huemer P (2000) Endemismus am Beispiel der Scythris fallacella (Schläger, 1874) - Gruppe (Lepidoptera: Scythrididae). Entomologische Zeitschrift Stuttgart 110(8): 244-249.

Lauber G, Wagner K (1996) Flora Helvetica. Bern, Stuttgart, Wien; Haupt, 1613 pp.

Passerin d'Entrèves P (1976) Revisione degli Scitrididi (Lepidoptera, Scythrididae) palearctici. II. - I tipi di Scythris del Muséum National d'Histoire Naturtelle di Parigi. Bollettino del Museo di Zoologia dell’Università di Torino 3: 27-70.
Ratnasingham S, Hebert PDN (2007) BOLD: The Barcode of Life Data System (http://www.barcodinglife.org). Molecular Ecology Notes 7: 355-364. http://dx.doi.org/10.1111/j.1471-8286.2007.01678.x

Schmitt T, Muster C, Schönswetter P (2010) Are Disjunct Alpine and Arctic-Alpine Animal and Plant Species in the Western Palaearctic Really "Relics of a Cold Past"? In: Habel JC, Assmann T (Eds) Relict species. Phylogeography and Conservation Biology. Springer, 239-252.

Schönswetter P, Stehlik I, Holderegger R, Tribsch A (2005) Molecular evidence for glacial refugia of mountain plants in the European Alps. Molecular Ecology 14: 3547-3555. https://doi.org/10.1111/ j.1365-294X.2005.02683.X

Steiner AJ (2002) Die Vegetation der Gemeinde Zermatt. Beiträge zur geobotanischen Landesaufnahme der Schweiz 74. Académie Suisse des Sciences naturelles, 204 pp. [Anhänge, Vegetationskarte u. CD]

SwissLepTeam (2010) Die Schmetterlinge (Lepidoptera) der Schweiz: Eine kommentierte systematisch-faunistische Liste. Fauna Helvetica 25, CSCF \& SEG, Neuchâtel, 959 pp.

Vives Moreno A (1984) Lista actualizada de la familia Scythrididae Rebel, 1901, de España y Portugal. Revista de Lepidopterología 12: 109-113.

Zerny H (1936) Die Lepidopterenfauna des Grossen Atlas in Marokko und seiner Randgebiete. Mémoires de la Société des sciences naturelles du Maroc 42: 1-163. 